$\xi=1$ 国

\title{
Distribution and ecology of Rafflesia in Royal belum state park, Perak, Malaysia
}

\author{
Farah Khaliz Kedri *, Zulhazman Hamzah, Nur Sayzwani Sukri, Siti Hajar Yaacob, \\ Nur Kyariatul Syafinie Abd Majid, Nasihah Mokhtar, Siti Fatimah Amir \\ Universiti Malaysia Kelantan Kampus Jeli, Peti Berkunci No 100, Jeli, 17600, Kelantan, Malaysia \\ *Corresponding author E-mail: farah.k@umk.edu.my
}

\begin{abstract}
Rafflesia, the biggest flowers in the world are considered as majestic and are made as ecotourism icons for several places in the South East Asia. Currently, a total of 34 species of Rafflesia were recorded in this region. 7 species of Rafflesia are found in Peninsular Malaysia alone. This study was executed in Royal Belum State Park in the state of Perak. An updated on distribution of Rafflesia and its ecology are provided. The Rafflesia population was mapped using Global Positioning System [GPS]. While the size of Rafflesia host-plant was measured with the measuring tape and the amount of rainfall was obtained from the Meteorological Department of Malaysia. During this study, there were 2 species of Rafflesia encountered in Royal Belum State Park, namely Rafflesia cantleyi Solms-Laubach and Rafflesia kerri Meijer. The species were recorded at X-Ray trail, Sg. Gadong, and Sg. Kooi. A total of 8 populations were set up from these locations. It was found that the population and the distribution decreased in accordance with the habitat interruption by human intervention and natural factors such as wildlife trampling on the immature buds. Besides, it was found that the number of Rafflesia buds increases with the class size for host-plant of Rafflesia with coefficients of determination of $\mathrm{R}^{2}=0.9866$. However, various physiological and environmental factors were taken into consideration in efforts of conserving this unique flower. This study is important in order to preserve the population of Rafflesia at Royal Belum State Park.
\end{abstract}

Keywords: Rafflesia distribution; ecology; Peninsular Malaysia

\section{Introduction}

Rafflesiaceae is a family of holoparasitic flowering plants that is most famous for its flower, which is known as the world's largest single flower Rafflesia arnoldii. Like any other holoparasitic plants, Rafflesiaceae rely on their host plant for water and nutrients [1]. As Rafflesia ia a holoparasitic plant, the known host plant for Rafflesia is Tetrastigma [Vitaceae] [2]. However, Rafflesia is categorized as endoparasite, which means it is entirely contained within its host plants and is only visible outside its host plant starting from 160 days after its germination process. 12 new species of Rafflesia have been identified and published by several Botanists [3]. Today, a total of 34 species of Rafflesia have been updated to exist in the Southeast Asia [4]is found in the tropical rainforests of Malaysia, Southern Thailand, Sumatra and Java, where it is warm all year round with an understandably high humidity. The Rafflesia is rare and especially hard to locate due to its brown coloured buds that are mostly found on the forest floor. These buds also possessed a camouflage appearance, similar to the dirt on the forest floor. It is difficult to see and find Rafflesia that is already blooming while the buds may take up to a long period of 10 months to develop. The flower lasts for 4 to 8 days, specifically 4 days of blooming and starting to rot at day 5 . Due to its long reproductive cycle, how many of these strange plants survived in the wild are still unknown. According to [5], there are three host plant of Rafflesia identified in Peninsular Malaysia, which are T. rafflesiae, T. diepenhorstii and T. hookeri.

\section{Literature Review}

The flowers of Rafflesia are of various sizes according to species and to date, 34 known species have been recorded. The species that is endemic to Malaysia is Rafflesia cantleyi, and it is common to see this species blooming in the state of Perak. For centuries, Rafflesia was believed and used by the indigenous people [Orang Asli] in Peninsular Malaysia to treat several illnesses [6, 7] Rafflesia is a very rare species. Some noted reasons for their rarity are the total dependency that it shows to its specific host plant [Tetrastigma] and most of the species shows dioecious charactersitics whereby male and female flowers do not usually bloom at the same time. This has caused imbalanced sex ratio, whereby the known male to female flower ratio is $7: 1$. According to [8] the fruit set percentage among female is low [35.71\%] with high bud mortality rate [40\% to $91 \%$ ] and in some worse cases, it was noted to be up to $100 \%$ [Nais, 2001]. Another vital factor for its rarity is its very long life cycle that can measure up to five years from seed to seed especially for Rafflesia arnoldii [9]. Therefore, the biology of Rafflesia still remains largely unknown until today due to their rarity.

Rafflesia will first show itself as a small protuberance emerging from the roots of several species of the Tetrastigma vine. From this, it will further take another 6 to 12 months to take the form of a pink-brownish 'cabbage', which later will bloom into a flower. Surprisingly, it has no leaves or lacking in photosynthetic tissue, stems or roots, and $[8,10,11]$ noted that the only vegetative parts of Rafflesia are the fine filaments that penetrate the tissue of the vine host. The flowers smell like rotten flesh and this attract several species of carrion flies or blowflies of the genus Lucilia and Chrysomya [Calliphoridae]. These flies become their pollinators or some believe that they are just visitors [12-14]. The flowers are unisexual too. After 6 to 9 months of successful pollination, the 
structure below the column of the female flower becomes the fruit Rafflesia's fruits hold thousands of small seeds that are said to be likely most dispersed by small mammals such as squirrels and tree shrews [10].

\subsection{Ecology of Rafflesia}

It is common for Rafflesia to grow in moist forest slopes that are located near the stream inside the forest. Most Rafflesia successfully blooms if located and grow near the stream. According to [3], because Rafflesia is a parasitic plant, the condition of the host plants, forest and the availability of water resource are the important keys to the survival of Rafflesia in their natural habitat.

The seasonal climate of South-east Asia may be the cause of the seasonal flowering in Rafflesia. In temperate zones where there is a clear seasonal pattern, most plants are induced to flower by the changing day length; this is called photoperiodism. In Peninsular Malaysia, the seasonality of the three Rafflesia species [R. cantleyi $R$. hasseltii, and $R$. kerrii] is unknown.

In the tropics, where there is no marked seasonal distinction [apart from the relative dry and wet seasons], phenology is less apparent and not as well understood. Probable cues that initiate flowering in tropical plants are variation in water availability, temperature and day length. Rainfall has a more significant effect because it varies greatly in amount and in seasonal distribution, while temperature has insignificant seasonal variation, and day length variation is minimal near the equator. Moreover, day length in some tropical environment probably has less effect because of the intermittent cloudiness, and because of the considerable shade the canopy provides for plants such as Rafflesia on the forest floor [8].

\subsection{Reproductive system}

The reproductive column in Rafflesia is in present of alternating longitudinal grooves and ridges. These features expand to the disk base and begin at the ring. The grooves are used to accommodate individual anthers in male flowers but they can also be found in female flowers. In female flowers however, this feature has a highly reduced stamen whorl. Moreover, the problem for Rafflesia is that its reproductive success is noted to be significantly low due to their rarity, low percentage of buds reach mature stage, a very momentary anthesis phase, a large gender difference [7:1], and rare occurrence of blooming both male and female flowers at the same time [15].

\subsection{Pollination}

There are few studies done about pollination in Rafflesia. The flowers are unisexual and a single Rafflesia population site usually produces either male and/or female flowers. It was found that in order to have successful pollination that later will result in successful reproduction process, male flowers must be in close range with female flowers, and preferably bloom at the same time as female flowers so that flies or any pollinating agents can pollinate the flowers [12]. Hence, in Rafflesia's survival, timing is the key. For pollination to occur, pollen from the anthers of male flowers must be transferred to the stigmas of female flowers by a pollinator. Rafflesia flowers are uniquely design by nature in such a way that its physical features are built to become attractive to potential pollinators. This includes providing primary attractant such as sticky masses of pollen that is yellow in colour, brooding places in the perigone tubes, and secondary attractants such as strong visual and scent [12]. Although male and female individuals could be closely spaced, flower bud mortality is recorded as high as 80 to $90 \%$ per population. This also reduced the chance of co-flowering the two genders of flowers [16].

\subsection{The phylogeny of Rafflesiaceae}

It is highly likely that the phylogeny of Rafflesiaceae is highly influenced by their interactions with their seed dispersers, host plants and pollinators. The pollination process of the entire family appears to be sapromyophily $[12-14,17-20]$. As a result of extreme parasitism, which at least underwent four times of independent evolution among former Rafflesiaceae [21, 22] it was found that a clade, which is substantiated by the large variation in gross morphology and pollen diversity among Rafflesiaceae members, is absent according to recent phylogenetic evidence [23]. A more detail floral size evolution study by [24] resulted in the prompt increase in floral size in larger flowered ancestors. His study resulted in somewhat the opposite of what we might think about floral evolution would be. As crucial as the seed to host plant penetration process need to be carried out in order to better understand the species, more extremely thorough and careful comparative study of the floral morphology of Rafflesiaceae is needed to explore more of the considerable transition between Rafflesiaceae and their small-flowered ancestors.

\subsection{Lifespan of Rafflesia}

The bud of Rafflesia is recognized first by swellings [ 2 to $4 \mathrm{~cm}$ in diameter] beneath the bark of trailing stems and roots of the woody vine Tetrastigma. The buds then rapidly grow in diameter and once a bud reaches about $20 \mathrm{~cm}$ in diameter, it opens gently in a 24 to 48 hours period. It is reportedly that Rafflesia begins to bloom at nighttime and then flowers for only 5 to 7 days. This however, causes a temporal congestion and slows down the process of pollination $[12,16]$. Current populations of Rafflesia in South East Asia are threatened by almost the same threat namely habitat destruction. This made matters [success for reproduction] worse and more complicated. Thus, as mentioned before, successful sexual reproduction depends on the right timing for a male and a female flower to bloom in close range from each other during the same 5 to 7 days. Rafflesia populations are often found to have wide distance between populations, so the ability of a fly or pollinators to carry pollen between these separated populations will also determine a successful sexual reproduction process.

After flowering, the plant withers and becomes a black mass of rotting plant tissue. Altogether, it is estimated it would take approximately 230 days [about 7.5 months] for Rafflesia bud to grow from initial swellings under the bark of Tetrastigma to anthesis. This is just the estimation for the cycle to start again from the swelling process. Another process that has yet to be studied is the penetration of Rafflesia seeds into its host plant. The detail process of how Rafflesia's miniscule seeds enter the tissue or cracks of its host plants' barks still remains a huge question in the biology of Rafflesia. It is anticipated that Rafflesia life cycle could reach 3 to 4.5 years.

\subsection{Ecology and behavior of holoprasitic plants}

Rafflesiaceae belongs to the family of holoparasitic endophytes. Their vegetative and reproductive bodies exhibit extreme modifications. They occupy among the most reduced vegetative body of all angiosperms despite having no recognizable roots and only a complicatedly modified fine white filaments body that contain a strand of cells. Another vegetative part of Rafflesia is their bract that predates before its flowers [25]. However, members of the family still produce the world's largest flowers even though very few vegetative parts are present in this unique plant.

Host plants' conditions are important factors to holoparasitic plants for their life continuance. Holoparasitic plants total dependency on their hosts caused them to die when the host plants are damaged or failed to compete with other plants. The availability of water resources in the respected habitat also play important role in order to ensure holoparasitic plants' survival. According to Akhriadi [3], the status and survival of Rafflesia highly correlates with their host plants' conditions. 


\subsection{Tetrastigma}

Tetrastigma are herbaceous or woody climbing vines that rely on other high plants in order for them to reach sun light in the dense forest. It is fairly usual that the plant's leaves are hard to find although the stem and root are recognizable in the forest. It has woody stem, with a relatively thick uneven, irregular surface. Tetrastigma can be easily damaged or split. This disadvantage is however, is beneficial to Rafflesia because it provides suitable space for the Rafflesia's seeds to establish. The existence of tendrils in Tetrastigma helps them to climb or hang to other trees. Previous records by [15] discovered 7 Tetrastigma species [Vitaceae] that were classified as Rafflesia host plants, which were Tetrastigma curtisii [Ridley] Suesseng, Tetrastigma diepenhorstii Miquel, Tetrastigma glabratum [Blume] Planch, Tetrastigma leucostaphylum [Dennst.] Alston, Tetrastigma papillosum [Blume] Planch, Tetrastigma quadrangulum Gapnep. and Craib, and Tetrastigma scortechinii [King] Gapnep.

\subsection{Medicinal uses of Rafflesia}

Because of its size, foul odour and grotesque appearances, the indigenous communities use Rafflesia for various medicinal purposes. Rafflesia is commonly called bunga patma: "bunga" is Malay for flower and "patma" is derived from the Sanskrit word for "lotus" that sybolizes fertility [10]. Extracts from the buds are used during post-partum to stop internal bleeding, shrink the womb, and restore fatigueness. Rafflesia was once recognized in the pre-Islamic Hindu culture of Java as a symbol of nature's reproductive forces [26]. Other traditional use of Rafflesia is that it is believed to have an aphrodisiac effect for men. Rafflesia is one of the ingredients of the two traditional medicinal preparations of ['Faizal tonic' and 'pil buasir'] sold in Perak, Malaysia [13]. Although Rafflesia is used in traditional medicine in many cultures, its chemical composition has not been extensively analyzed. Preliminary phytochemical screening has not found any basis for its purported medicines properties [27]. In fact, Rafflesia buds and flowers are known to be rich in tannins and phenol; compounds which may be toxic if taken in excess quantity [28].

\subsection{Conservation status of Rafflesia in Malaysia}

In early 1988, the public put a big pressure to the state when the type locality of newly found Rafflesia tengku-adlinii in Sabah was lost. In accordance to this, a state-level committee was formed for the purpose of Rafflesia conservation in Sabah. The committee's major responsibility was to strategically plan to maintain a bona fide balance between forest benefiting and the preservation of selected Rafflesia conservation areas. As a result from this, a Rafflesia Forest Reserve was gazette in Tambunan.

The use and clearing of land for development purposes raises serious threats for Rafflesia. Now, Rafflesia is facing a danger of extinction as their habitats are destroyed. The consequences of decreasing number of Rafflesia in Malaysia affect ecotourism activity. According to [8], thousands of people go to Sabah and other parts of Malaysia annually to see a blooming Rafflesia flower.

\section{Methodology}

The study area is located at the upper level of Belum area with a reported total coverage of about 290,000 hectares [Figure 1]. Royal Belum State Park is located to the south of Thailand and in the east of Kelantan. It is in close propinquity with Thailand's Bang Lang National Park and Hala-Bala Wildlife Sanctuary. The Belum area is divided into lower and upper sections where a highway divides the park area in the north and Temengor Forest Reserve to its south. The landscape of Royal Belum State Park consists of forest, small areas of grassland, and abandoned agricultural plots. It also includes a man-made lake called Tasik Temengor. The forests types in the area are mainly lowland dipterocarp, hill dipterocarp and upper dipterocarp forests. The Upper Belum area covers 117,500 hectares of impenetrable jungle that stretches into the Thai-Malaysian border in northern Peninsular Malaysia. This large jungle patch acts as a natural barricade and is gazette as a security zone.

Field surveys were conducted to determine the Rafflesia distribution and ecology. The surveys were done in Royal Belum State Park, involving three localities namely X-Ray trail, Sungai Kooi and Sungai Gadong. The areas of Sungai Gadong were divided into six, which are Sungai Gadong Limau 1, Sungai Gadong Limau 2, Sungai Gadong A1, Sungai Gadong A2, Sungai Gadong B1 and Sungai Gadong B2. Each Rafflesia population was identified through DGPS [Digital Global Positional System] and marked with a tag. The number of buds, flowers and fruits in the areas were counted, photographed and recorded. The photographs were taken with a digital camera [Canon PowerShot G12]. The size of the Rafflesia host plant was measured by using the measuring tape. The data for amount of rainfall is obtained from the Meteorological Department of Malaysia. Rafflesia species from the study area were identified according to [21] and [10].

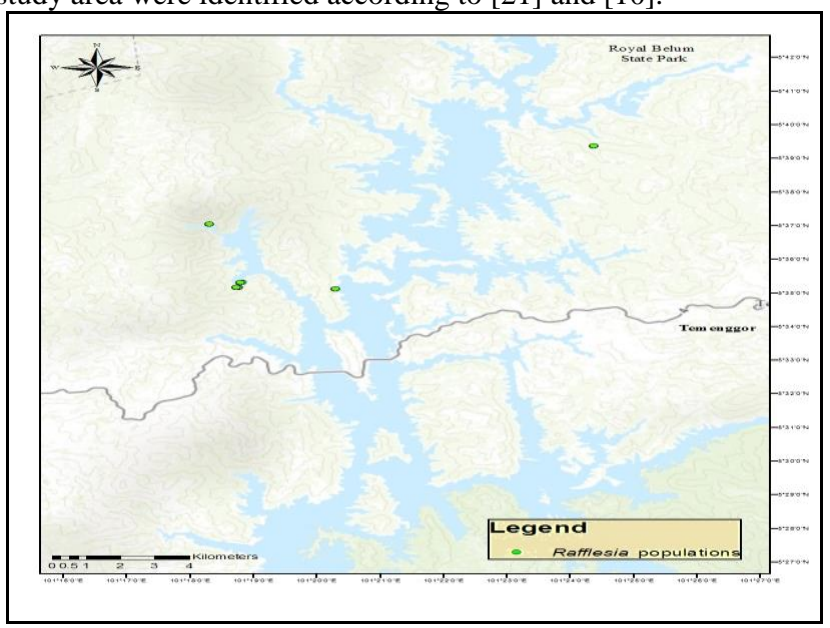

Fig. 1: Topographic map of Rafflesia population at Royal Belum State

\section{Results and findings}

A total of 122 buds, 16 flowers and 4 fruits were observed during the survey [Table 1]. The highest number of buds was found at XRay Trail, with a total of 44 buds while the lowest number of buds was found at Sungai Gadong 2, with no bud at all, but only a flower. The distributions of the populations were not uniformed. Compared to a study, which was done by Siti Munirah [29] there were obvious changes in the number of population and location. According to Siti Munirah [29] there were 7 localities of Rafflesia recorded at Royal Belum such as Sg. Ruok, Sg. Gadong, Sg. Tan Hain, Sg. Selantan, Sg. Kejar, Belum Lama and Sg. Kenarong. Therefore, it was found that the distribution of Rafflesia had been decreased during the field survey after only three localities were encountered. There were 2 species of Rafflesia found namely Rafflesia cantleyi and Rafflesia kerri [Figure 3E and 3F] respectively.

Table 1: Rafflesia population at Royal Belum State Park

\begin{tabular}{|c|c|c|c|c|c|c|}
\hline $\begin{array}{c}\mathbf{P} \\
\mathbf{l} \\
\mathbf{t}\end{array}$ & Location & $\begin{array}{c}\text { Number } \\
\text { of living } \\
\text { bud }\end{array}$ & $\begin{array}{c}\text { Number } \\
\text { of died } \\
\text { bud }\end{array}$ & $\begin{array}{c}\text { Total } \\
\text { number } \\
\text { of bud }\end{array}$ & $\begin{array}{c}\text { Number } \\
\text { of } \\
\text { Flower }\end{array}$ & $\begin{array}{c}\text { Sta } \\
\text { tus }\end{array}$ \\
\hline 1 & X-Ray & 39 & 5 & 44 & 9 & $\begin{array}{c}\text { Dy } \\
\text { na } \\
\text { mic }\end{array}$ \\
\hline 2 & Sg. Kooi & 8 & 5 & 13 & 3 & $\begin{array}{c}\text { Dy } \\
\text { nic } \\
\text { mic }\end{array}$ \\
\hline 3 & $\begin{array}{c}\text { Sg. } \\
\text { Gadong } \\
\text { Limau 1 }\end{array}$ & 0 & 2 & 2 & 0 & $\begin{array}{c}\text { Dor } \\
\text { ma } \\
\text { nt }\end{array}$ \\
\hline 4 & $\begin{array}{c}\text { Sg. } \\
\text { Gadong } \\
\text { Limau 2 }\end{array}$ & 9 & 3 & 12 & 0 & $\begin{array}{c}\text { Ac- } \\
\text { tive }\end{array}$ \\
\hline
\end{tabular}




\begin{tabular}{|c|c|c|c|c|c|c|}
\hline 5 & $\begin{array}{c}\text { Sg. } \\
\text { Gadong } \\
1 \\
\end{array}$ & 4 & 0 & 4 & 3 & $\begin{array}{l}\text { Dy } \\
\text { na } \\
\text { mic }\end{array}$ \\
\hline 6 & $\begin{array}{c}\text { Sg. } \\
\text { Gadong } \\
2\end{array}$ & 0 & 0 & 0 & 1 & $\begin{array}{l}\text { Ac- } \\
\text { tive }\end{array}$ \\
\hline 7 & $\begin{array}{c}\text { Sg. } \\
\text { Gadong } \\
\text { B1 } \\
\end{array}$ & 29 & 5 & 34 & 0 & $\begin{array}{l}\text { Ac- } \\
\text { tive }\end{array}$ \\
\hline 8 & $\begin{array}{c}\text { Sg. } \\
\text { Gadong } \\
\text { B2 }\end{array}$ & 11 & 2 & 13 & 0 & $\begin{array}{l}\text { Ac- } \\
\text { tive }\end{array}$ \\
\hline & $\begin{array}{c}\text { Total } \\
\text { Min } \\
\text { Max }\end{array}$ & $\begin{array}{c}100 \\
39\end{array}$ & $\begin{array}{c}22 \\
5\end{array}$ & $\begin{array}{c}122 \\
0 \\
44\end{array}$ & $\begin{array}{c}16 \\
9\end{array}$ & \\
\hline
\end{tabular}

\section{*Status:}

Active : The population has one stage of bud growth only

Dormant: The population only has host with many scars and no new buds found

Dynamic: The population has all stage of bud/flower growth

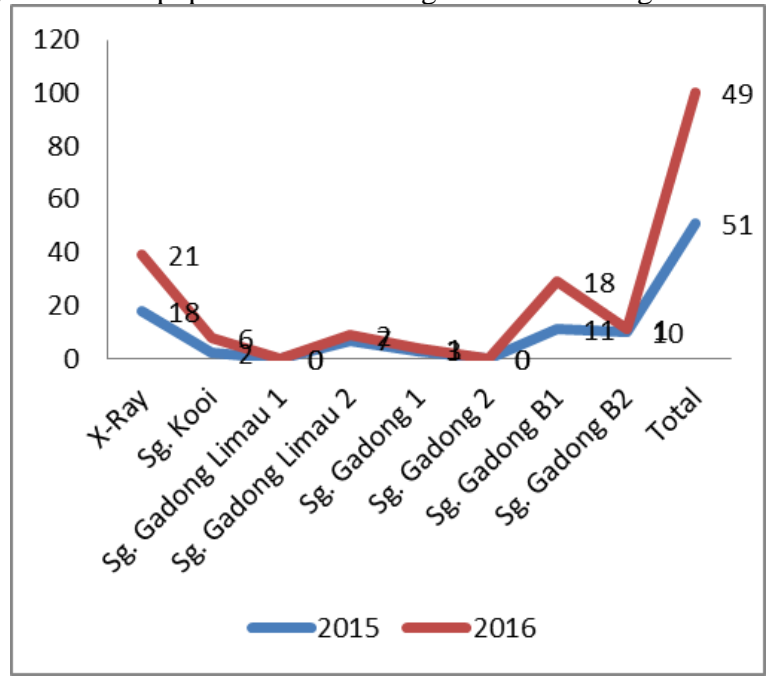

Fig. 2: Number of Rafflesia buds at study site

From the study, it showed that number of buds at all location slightly decreased from year 2015 to 2016, except for X-Ray and Sg. Gadong B1 [Figure 2]. At these two locations, the number of buds increased $7.7 \%$ and $24.1 \%$ respectively. Dead buds were also recorded. During this study the highest number of dead buds encountered was at $\mathrm{Sg}$. Kooi with a total number of 4 dead buds. Dead buds may be caused by numerous factors, amongst which are trampling by wild animals, trekking activities, collection by local people for traditional medicinal purposes and many more Moreover, the study site is a tourist attraction

Table 2: Total number of living buds and annual rainfall

\begin{tabular}{|c|c|c|}
\hline Year & $\begin{array}{c}\text { Total no. of liv- } \\
\text { ing buds }\end{array}$ & Annual rainfall [mm] \\
\hline 2015 & 51 & 1939.9 \\
\hline 2016 & 49 & 1779.3 \\
\hline
\end{tabular}

During the study period, it was also observed that buds that were located in the higher vines tend to die before at early stage. This was most likely because when the buds emerges high up the vines, gravity took control and the weight of the buds just simply couldn't handle the height. Many buds died and fell to the forest floor. This was really difficult to record as most of the times, the fallen buds were very hard to recognize, and many more rot. Rafflesia and its host plants reported to thrive in warm climate with high humidity, however slight difference in annual rainfall between year 2015 and 2016 did not cause apparent change in number of Rafflesia buds, whether they increase or decrease [Table 2]. This factor cannot be deemed as the sole dfactor that influence Rafflesia population growth. It was reported by [30] an attempt to cultivate Rafflesia patma by transferring an infected Tetrastigma vine from the wild to the garden were successful, with several buds emerged few years after the vine was transferred.
From this study, it was found that the class size of Tetrastigma sp. that was between $51-60 \mathrm{~cm}$ beared higher number of buds compared to other smaller and younger size of Tetrastigma. The occurrence and especially the well-being of the host plant are very crucial for Rafflesia to grow [31]. This showed that Tetrastigma that already matured was suitable for the buds to grow effectively. In this case, the larger the host plant, the more buds it can carry. Therefore, bigger host plant sizes usually accommodate a larger Rafflesia population.

Table 3: Class size for host-plant of Rafflesia

\begin{tabular}{|c|c|}
\hline Class size of Tetrastigma [cm] & Number of buds \\
\hline $1-10$ & 0 \\
\hline $11-20$ & 5 \\
\hline $21-30$ & 4 \\
\hline $31-40$ & 4 \\
\hline $41-50$ & 1 \\
\hline $51-60$ & 11 \\
\hline
\end{tabular}

Field survey also noted that more buds grew on bigger host plant. Some buds hang like a shower from the vines of the host plant. Besides, it was found that the number of Rafflesia buds increases with the class size for host-plant of Rafflesia with coefficients of determination of $\mathrm{R}^{2}=0.9866$. When the host plant is bigger in size, the more nutrients it contained and this meant more Rafflesia population on the host plants' vines. Moreover, bigger sized host plants can accommodate the naturally big and heavy Rafflesia mature buds and flowers. During field survey, it was also noted that smaller sized host plants tend to break or damaged before the buds reach maturity period and this lower the chances of survival for Rafflesia.

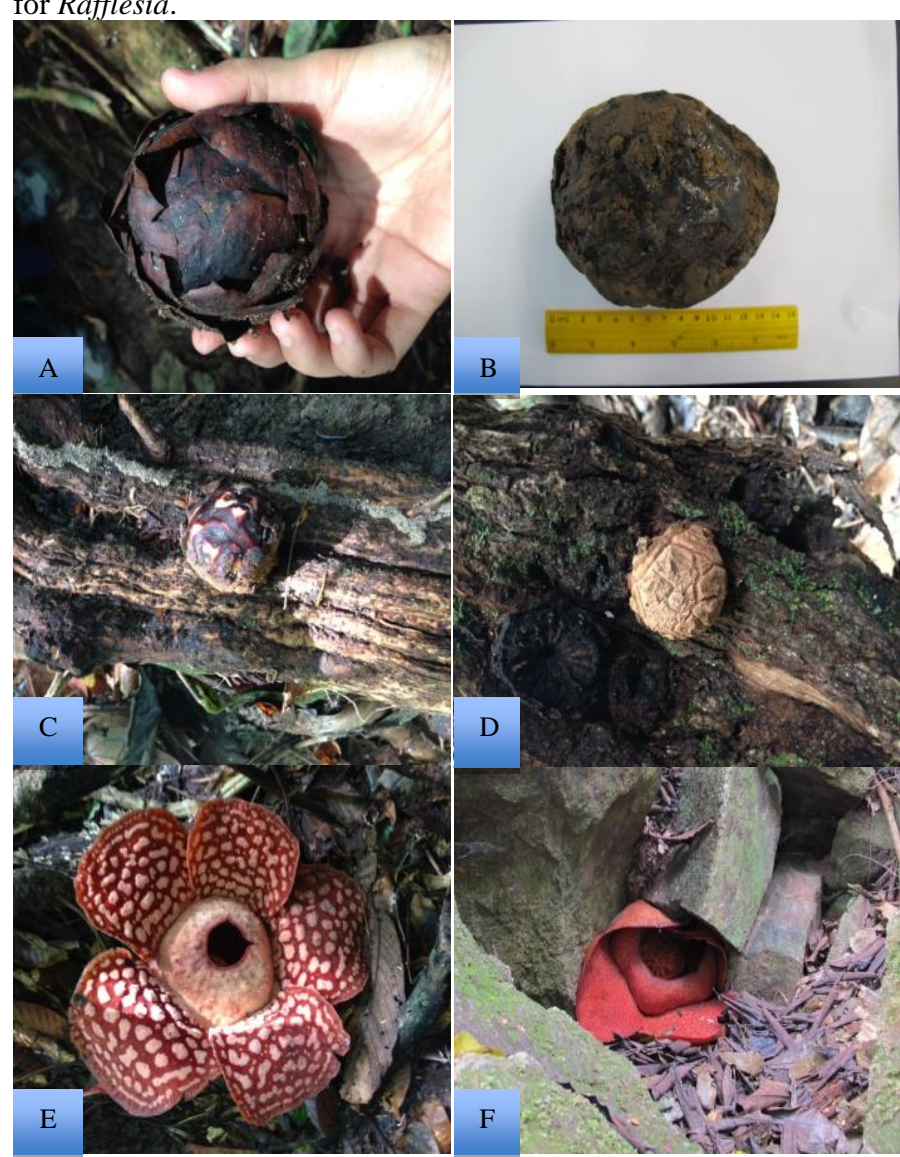

Figu. 3: A] Rafflesia cantleyi [Bract stage], B] Unripe fruit of $R$. cantleyi, C] Rafflesia cantleyi [Cupule-bract stage], D] Rafflesia cantleyi [Cupule stage], E] Rafflesia cantleyi bloomed at Sg. Gadong 1 [Anthesis stage], F] Rafflesia kerri bloomed between the rocks at Sg. Kooi [Anthesis stage]

As a holoparasitic plants, life continuity of Rafflesia depends on the health condition of their host plants and most importantly the accessibility of water resources in their habitat. Rafflesia becomes vulnerable especially whenever its host plants die or damaged. According to [15], status and existence of Rafflesia have high correlation with the living condition of their host plants. The 
population size also varies by species and is normally dependent [11] on the size of the host and size of bud and flowers. The larger the host, the larger number of buds and flowers it is able to support. The ecological requirements of host plants also play a vital role in Rafflesia conservation.

\section{Conclusion}

The update distribution of Rafflesia population at Royal Belum State Park is presented and it is getting decreased in number from previous study. Besides, the number of bud emergences on the Rafflesia host plant is affected by the size of Rafflesia host plant. Because Rafflesia is totally dependent on its host plant, it is crucial to conserve the host plant itself in order to conserve Rafflesia. Thus, throughout the study that had been done, all the data will be very crucial as references for Rafflesia conservation effort in the future.

\section{Acknowledgement}

This material is based upon work supported by Malaysian Ministry of Higher Education [MOHE] under grant no. R/RAGS/A08.00/01216A/001/2015/000223. The author would also like to thank Faculty of Earth Science, Universiti Malaysia Kelantan Jeli Campus, Pulau Banding Foundation [PBF] and Perbadanan Taman Negeri Perak [Taman Negeri Royal Belum] for the cooperation during the research period.

\section{References}

[1] Kuijt J. The Biology of Parasitic Flowering Plants: University of California Press; 1969 October 1, 1969. 368 p.

[2] Nickrent DL. Parasitic Plants of the Iberian Peninsula and Balearic Islands. Parasitic Plants of the World. . 2002. p. 7-27.

[3] Akhriadi P, HA. Kiswanto, A. Taufiq, D. Alfajri \& R. Kadirman. Assessment of Conservation Status of Rafflesia in West Sumatra, Indonesia. Padang: Rafflesia Monitoring Team [RMT] Padang, 2010.

[4] Wan Zakaria WNF, Ahmad Puad AS, Geri C, Zainudin R, Latiff A Tetrastigma diepenhorstii [Miq.] Latiff [Vitaceae], a New Host of Rafflesia tuan-mudae Becc. [Rafflesiaceae] in Borneo. Journal of Botany. 2016:1-6.

[5] Mokhtar N, Hamzah Z, Munirah MS, Arifin WNNW, Latiff A Tetrastigma hookeri [Laws.] Planch.[Vitaceae], a host plant for Rafflesia kerri Meijer in Peninsular Malaysia. Malayan Nature Journal. 2016;68 No 1 \& 2:33-9.

[6] Thulaja NR. NLB National Library Board Singapore Rafflesia 2-25 Singapore2003. Available from: http:// www.nl.sg/.

[7] Kanchanapoom T, Kamel MS, Picheansoonthon C, Luecha P, Kasai R, Yamasaki K. Hydrolyzable tannins and phenylpropanoid from Rafflesia kerrii Meijer [Rafflesiaceae]. Journal of Natural Medicines. 2007;61[4]:478-9.

[8] Nais J, Wilcock CC. The Rafflesia conservation incentive scheme in Sabah, Malaysia, Borneo. Sabah Parks Nature Journal 1998;1:9-17.

[9] Meijer W, Riedl H, Huang TC, Saunders RMK, Barlow BA, Kalkman C, et al. Flora Malesiana. Series 1, Spermatophyta Volume 13, Rafflesiaceae, Boraginaceae, Daphniphyllaceae, Illiciaceae \& Schisandraceae, Loranthaceae \& Viscaceae: Rijksherbarium; 1997.

[10] Meijer W. Saving the World's Largest Flower. National Geographic. 1985;168[1]:0
Ismail G. Conservation of the giant Rafflesia in Sabah, Malaysia. Trends in Ecology \& Evolution. 1988;3[12]:316-7.

[12] Beaman R, Decker P, Beaman J. Pollination of Rafflesia [Rafflesiaceae]. American Journal of Botany. 1988[75]:1148-62.

[13] Bänziger H. Stench and fragrance: unique pollination lure of Thailand's largest flower, Rafflesia kerrii Meijer. Nat Hist Bull Siam Soc. 1991;[39]:19-52.

[14] Bänziger H. Pollinaion of flowering oddity: Rhizanthes zippeli [Blume] Spach [Rafflesiaceae]. Nat Hist Bull Siam Soc. 1996;[44]:113-42.

[15] Nais J. Rafflsia of the world. First Edition ed. Malaysia: Natural History Publications [Borneo]; 2001 January 1, 2001.

[16] Nais J, Baikan B, Sinun W. Nature conservation: striking a balance between conservation and development for Sabah beyond 2000 . Sabah Beyond. 2000:181-202.

[17] Bänziger H. Studies on the superlative deceiver: Rhizantes Dumortier [Rafflesiaceae]. Bulletin of the British Ecological Society. 2001;32[3]:36-9.

[18] Bänziger H. Studies on hitherto unknown fruits and seeds of some Rafflesiaceae, and a method to manually pollinate their flowers for research and conservation. Linzer Biology Beitr. 2004;36[2]:117598.

[19] Hansen B, \& Bänziger, H. Unmasking the real identity of Sapria poilanei Gagnepain emend., and description of Sapria ram sp.n. [Rafflesiaceae]. Nat Hist Bull Siam Soc. 1997;[45]:149-70.

[20] Bãnziger H, Pape T. Flowers, faeces and cadavers: natural feeding and laying habits of flesh flies in Thailand [Diptera: Sarcophagidae, Sarcophaga spp.]. Journal of Natural History. 2004;38[13]:1677-94. Barkman TJ, Seok-Hong Lim, Kamarudin Mat Salleh, Nais J. Mitochondrial DNA sequences reveal the photosynthetic relatives of Rafflesia, the world's largest flower. Proceedings of the National Academy of Sciences of the United States of America. 2004;101[3]:787-92.

[22] Nickrent DL, Blarer A, Yin-Long Q, Vidal-Russell R, Anderson FE Phylogenetic inference in Rafflesiales: the influence of rate heterogeneity and horizontal gene transfer. BMC Evolutionary Biology. 2004;4:40-17.

[23] Takhtajan A, Meyer N, Kosenko V. Pollen morphology and classification in Rafflesiaceae. 1985;s.1. Bot Zurn. [Moscow and Lenigrad][70]:153-62.

[24] Barkman TJ, Bendiksby M, Lim S-H, Salleh KM, Nais J, Madulid D, et al. Accelerated Rates of Floral Evolution at the Upper Size Limit for Flowers. Current Biology. 2008;18[19]:1508-13.

[25] Nikolov LA, Tomlinson PB, Manickam S, Endress PK, Kramer EM, Davis CC. Holoparasitic Rafflesiaceae possess the most reduced endophytes and yet give rise to the world's largest flowers. Annals of Botany. 2014;114[2]:233-42.

[26] Blume CL. Bijdragen tot de flora van Nederlandsch Indie: Batavia :Ter Lands Drukkerij,1825-1826.; 1825.

[27] Jubil M. Kajian ekologi dan taksonomi Rafflesia di Sabah [Unpublished undergraduate thesis], Jabatan Biologi, Universiti Kebangsaan Malaysia Kampus Sabah, Kota Kinabalu. 1984

[28] Wong M, Latiff A. Rafflesias of Peninsular Malaysia. Nature Malaysiana. 1994;19[3]:84-8.

[29] Siti Munirah MY. Rafflesia blooms in Royal Belum. Conservation Malaysia A Bulletin Supporting Plant and Animal Conservation in Malaysia. 2012[No.16].

[30] Mursidawati S, Ngatari, Irdawati, Cardinal S, Kusumawati R. Ex situ conservation of Rafflesia patma Blume [Rafflesiaceae] - an endange ed emblematic parasitic species from indonesia. The Journal of Botanic Garden Horticulture. 2015;No.13:99-109.

[31] Barcelona JF, Pelser PB, Balete DS, Co LL. Taxonomy, ecology, and conservation status of Philippine Rafflesia [Rafflesiaceae]. Blumea - Biodiversity, Evolution and Biogeography of Plants. 2009;54[1]:77-93. 